\title{
招待論文 \\ 構造設計基準の合理化とその国際標準化 \\ RATIONALIZATION OF DESIGN CODE AND ITS GLOBAL STANDARDIZATION
}

\author{
古田 均 ${ }^{1}$. 佐藤尚次 ${ }^{2}$ \\ Hitoshi FURUTA and Naotsugu SATO \\ 1 正会員 工博 関西大学教授 総合情報学部総合情報学科 \\ （广 569-1095 大阪府高柣市霊仙寺町 2-1-1) \\ E-mail : furuta@res.kutc.kansai-u.ac.jp \\ 2 正会員 工博 中央大学教授 工学部土木工学科 \\ （テ 112-8551 東京都文京区春日 1-13-27） \\ E-mail : sato@civil.chuo-u.ac.jp
}

Key Words : design standard, globalization, performance-based design, rationalization, reliability-based design

\begin{abstract}
本文では, 安全性向上・長寿命化を目指すために構造設計はどうあるべきか, またそれを実現するた めに設計基準はどうあるべきかという問題について考える. そのための方法として, 信頼性設計, 性能 照査型設計を取り上げ，本テーマに対する若干の考察を行い，国際設計標準という観点からいくつかの 問題点について述べる. まず, 構造設計の合理化に関する歴史を概観し, その後信頼性設計, 性能照査 型設計に関する若干の考察を行う。その後, 本文の主目的である設計標準の国際化に関する実情とその 実現に向けての今後の課題について述べる.
\end{abstract}

\section{1. はじめに}

構造設計の目的は, いうまでもなく“良い”構造物を 造ることである.この“良い”という言葉の中に, “安 全で”, “経済的で”, “耐久性があって”, “使い勝手が 良くて”, “美しい”等の種々の要因（要求性能）が含 まれている.もちろん, これらすべて，あるいはそれ 以上の要求を最大限に満たす構造物を造ることが望ま れる.ところが，明らかに，これらの要因のいくつか はドレード・オフの関係にあり, すべての要求を最大 限満たすことは困難である.この困難な課題をいかに 解決し実際的な解を見出すかが，設計者，技術者の腕 の見せ所であった．しかしながら，近年このような技 術者としての視点からだけでは“良い”設計の実現が 困難になってきている.

すなわち, 最近の新しい社会潮流として, 国際化, IT, 高齢化・少子化, バリアフリー, 環境にやさしい, 等の多くの問題が取り上げられ幾多の議論がなされて いる. もちろんどの問題も緊急を要するもので, 非常 に大事なものであり，しかも従来の考え方，方法論で は適切な解が得られないものである. その中でも, 今 日の地球規模のグローバリゼーション，そして世界貿 易機構（WTO）による市場開放と TBT 協定によるあ らゆる分野での国際整合性の要求を考えると，国際化
の問題は火急的速やかに対処しなければならない重大 問題の一つである.土木分野では，国際設計標準化の 波にどのように対処していき，その中でわが国として どのような方法を提案していくかが非常に重要な課題 である.

今までの日本では, 高度経済成長を維持するために も社会基盤システムの整備が不可欠であるとの認識に 立ち, 数多くの構造物が短期間の間に建設されてきた. その間, 構造物が年を経るにつれ, 様々な問題点が指 摘されるようになってきている. 現在, わが国の経済 は右肩上がりから停滞期に入り, 社会基盤施設の整備 も再検討す心゙き時にきている. もちろん, 従来までの 社会基盤システム整備の考え方自体が根本的に間違っ ていたわけではなく, 周りを取り巻く環境変化, 特に 自然環境, 社会環境, 経済環境などの変化に伴い構造 物の計画, 設計, 施工, 維持管理等を見直すべき時にき ている.すなわち,「経済性を損なうことなく, 構造物 の耐久性を上げ長寿命化を図る」ことが 21 世紀のキー ワードになってきている.

バブル経済がはじけ，経済状態に閉塞感がある今日， 公共構造物のあり方に対する議論も活発となっており， また情報公開という立場からも構造設計のあり方, そ れをスムーズに実現するための設計基準のあり方につ いて議論する必要があろう. さらに, わが国固有の条 
件を勘案し，設計基準がどうあるべきかについて討議 することはもちろん必要であるが，広く世界に目を向 け，世界の動向を把握し，世界の中でのわが国の設計 基準がどうあるべきかについて考えることも重要であ ろう.

本文では, 安全性向上・長寿命化を目指すために構 造設計はどうあるべきか，またそれを実現するために 設計基準はどうあるべきかという問題について考えて みたい. そのための方法として, 信頼性設計, 性能照 查型設計を取り上げ，本テーマに対する若干の考察を 行い，国際設計標準という観点からいくつかの問題点 について述べる．今までわが国において「国際化」と いう言葉はよく使われてきているが, その割には本質 的な議論はそれほどされず，枕詞的な使われ方がほと んどであった．日本人のメンタリティーからいって， 情緒的な議論が多く，原則論が苦手であったこと，国 際化といっても本当の意味でその必要性がなかったこ と，などが原因であろう。これに対し，ヨーロッパ諸 国では，構造設計の標準化に関する原則の確立に向け て，長期間絶え間ない努力が続けられてきている.す なわち, 1947 年に結成された ISO（国際標準化機構） の活動がその典型的なものである. 国際標準といって も各国には独自の文化, 背景があり, 簡単に国際標準 が制定できるわけではなく，標準化と同時に多様化に 関する議論が不可欠である.

まず，構造設計の合理化に関する歴史を概観し，そ の後信頼性設計, 性能照査型設計に関する若干の考察 を行う。その後, 本文の主目的である設計標準の国際 化に関する実情とその実現に向けての今後の課題につ いて述べる.

\section{2. 構造設計法の変遷}

従前は構造物の設計基準といえば，許容応力度設計 法が用いられてきたが，現在各国の設計基準の多くは 限界状態設計法に基づいたものとなっている，限界状 態設計法とは,「終局限界, 使用限界等の構造物にとっ て危険あるいは好ましくない状態を限界状態という形 で明確に定義し, 各限界状態に対する安全性がバラン スよく達成されることを目指したもの」と定義付けら れることが多い1)，限界状態設計法は，歴史的にみる と, 部分安全係数設計法と荷重係数設計法からなって いる．以下に，構造設計法の変遷を信頼性設計の観点 からまとめてみる ${ }^{1)}$.

限界状態設計法の起源は, Mier-Leibnitz の終局強度 設計理論に基づく設計といわれる. 1939 年旧ソ連で終 局強度に着目した設計法に関する研究がコンクリート
および鉄筋コンクリート部材に関して始められた。そ の後, 1950 年に限界状態設計法の基準案としてその成 果がまとめられた. 1954 年には西欧諸国に紹介され, 1964 年, 1970 年, 1976 年の CEB/FIP の基準案が出 され，今日に至っている. 限界状態設計法は, 文字通 り種々の限界状態に注目し, それらの照査を統一的に 行うものであるから，言葉のもつ意味からは, 確率論 に基盤を置く必要はないが，その歴史的経緯から確率 論を切り離すことはできない. 限界状態設計法の研究 が旧ソ連で始められたとき，すでに確率的な取扱いが 検討されていたと言われている. CEB/FIP 等の限界 状態設計法においては, Torroja (1958) の研究を端緒 として確率的な方法論の導入が図られている. すなわ ち, 限界状態設計法の初期の段階では, 確率論に直接的 な基盤を置いてはいなかったが，信頼性理論の発展に 伴い確率統計的な考え方を導入してきている．他の限 界状態設計法の顕著な特徵の一つとして, 単一ではな く複数の安全係数 (部分安全係数) が用いられている ことが挙げられる. 部分安全係数は Basler (1960) の論 文から限界状態設計法での使用が検討され, 示方書上 の規定は複雑になるものの, 合理的な設計が可能にな ると認められて全面的な採用に至っている.このヨー ロッパの部分安全係数設計法に対し, アメリカでは荷 重係数設計法が提案され, AASHTO を始め, 多くの設 計基準に取り入れられている. 歴史的な過程の違いは あるものの, 現在部分安全係数設計法と荷重係数設計 法には根本的な違いはなく，それを総称して限界状態 設計法ということもできる.

信頼性設計法という観点から整理したが，それでは 信頼性設計法とは何かというと, 最も他の設計法と異 なる所は, 構造設計を取り巻く環境下では, 不確実性, 不確定性が存在することを容認し, それを明確にして 合理的な設計法を打ち立てようという点である.もち ろん, どの構造設計法でもこの不確実性, 不確定性の存 在は認識されているが, 設計基準に明確に現れていな い. この不確実性を前面に出すことによって, 経済性 の議論をより明確にすることができる．たとえば，信 頼性設計として以下の定式化を考えることができる.

$$
C_{T}=C_{I}+C_{F} \cdot P_{f} \Rightarrow \mathrm{MIN}
$$

ここで， $C_{T}$ は全期待損失費用， $C_{I}$ は初期建設費用， $C_{F}$ は破壊時損失費用, $P_{f}$ は破壊確率である.この全 期待損失費用の最小化を図ることにより，構造物の合 理性が議論できることになる，いうまでもなく，現実 には，これら $C_{F}, P_{f}$ の評価は非常に困難であり, 実 際の設計にこの考え方を直接反映させることは容易で はない. そこで, 初期建設費を最小にするという次の 定式化も考えられている. 


$$
\begin{array}{ll}
\text { 目的関数: } & C_{I} \Rightarrow \mathrm{MIN} \\
\text { 制約条件 : } & P_{f} \leqq P_{f a}
\end{array}
$$

ここで， $P_{f a}$ は許容破壊確率である.ただし， $P_{f}$ に破 壊確率という言葉を用いているが，破壊とは必ずしも 物理的な破壊のみではなく，ある限界状態をさすもの で，使用限界状態も含まれる.

現在のわが国の経済状況を考えると，構造物の安全 性の向上と長寿命化が望まれる。ももろん,これらは経 済性に基づいた合理的なものでなければならない，性 能設計はこの合理性に基づく安全性向上と長寿命化に 有効であると考えられる，たとえば，構造物の長寿命 化には，最初に多くの費用をつぎ込み耐久性の高い構 造物を造ることは有効であるが，維持管理を当初から 設計に考慮しておき, 維持管理をしっかり行うことに より構造物の寿命を延ばすことも考えられる．最近よ く聞かれるライフサイクルコストを考慮した設計であ る. このとき, 設計問題は以下のように定式化される.

$$
L C C=C_{I}+C_{F} \cdot P_{f}+C_{M}+C_{R} \Rightarrow \mathrm{MIN}
$$

ここに, $L C C$ はライフサイクルコスト, $C_{M}$ は維持管 理費用， $C_{R}$ は取替えの費用である. このことは，長寿 命化を目指した設計法では, 狭義の設計に維持管理の 考え方を導入する必要があることを示している．とこ ろが，維持管理は，時間が経たないと本当の意味がわ からないため; 長寿命化には点検, 検查, 維持管理技 術とその効果の評価が必要不可欠となる.

\section{3. 性能照査型設計法}

式 (2)の定式化に従えば，問題は制約条件をどのよう に規定するかということになる．この制約条件は，要 求条件, 要求性能とも考えられ, 昨今注目されている 性能照査型設計法に通じるものである．性能照査型設 計法の統一的な定義はまだ確立されていないので，厳 密な議論はここでは避けるが，「性能設計とは，与えら れた外的条件（荷重）に対して，規定された目標性能 を満足するように行われる設計行為である」2) とする と, 上述の限界状態設計さらには信頼性設計法は性能 照査型設計法ということもできる。

わが国では, 阪神淡路大震災の後, 特に耐震基準の 性能設計化ということで多くの議論がなされているが, 性能設計の歴史は古く，特に建築分野では 1930 年に英 国建築研究所 (BRS) が要求性能に基づいて健康と安全 とを検討すべきであると提案している. ISO は 1970 年 に性能概念の規格への適用検討を開始し，1980 年に建 築性能に関する最初の ISO 規格を制定している．わが
国では，1963 年に雑誌「新建築」に建築の性能評価の 連載がされ，1970 年から建設省を中心に性能設計に関 する種々の試みがなされている，1973 年建設省は総プ ロ「住宅性能総合評価システムの開発」を開始し, 1978 年にも同総プロを実施し, 1994 年性能を基盤とした建 設省総プロ「新建築構造体系の開発」を開始している. 1998 年建築基準法が性能規定化で改定され，1999 年 には「住宅の品質確保の促進に関する法律」が制定さ れている。

もちろん，これら建築分野における性能設計一の一 連の動きは注目に値するが，土木構造物と建築構造物 の違いを十分認識して議論する必要があることはいう までもない，前述したように，土木分野ではこの性能 設計については耐震設計基準と維持管理問題について 盛んに議論されている．この背景には，わが国を取り 巻く国外からの社会要請（後で詳述する）もあるが, 阪 神淡路大震災時の被害状況からこれまでの設計地震力 および設計手順の詳細を規定した仕様設計基準では, 設 計された構造物が設計荷重以上の荷重に対してどの程 度耐えうるかという疑問に答えられないことがある ${ }^{3)}$. これに対し，構造物の耐力は，地震の発生頻度や構造 物の重要度を基に決定されるべきであるとし，その要 求性能を明確にすべきであると考えると, 性能設計が 望まれることになる．SEAOCの Vision 2000 では，地 震荷重と構造物ごとに，まず目標性能を設定し，これ を満足するように設計を進めるのが性能設計と定義さ れている3).ささらに, 設計が目標性能を満足するかど うかを立証するために，許容される基準の定量化が必 要であるとされている. いずれにしても構造物の要求 性能を明確にし，それを満たすものの中で最も経済性 に富むものが望まれるわけである。

\section{4. 設計標準の国際化}

\section{(1) 国際化について}

現在情報の分野では，インターネット等の驚異的な 発展により，真の意味でボーダーレスとなっている. 情報といういわゆるソフトウェアに属するものだけで なく, 自動車, 船, コンピュータ本体等のハードウェ アに関わるものもボーダーレスに近い状態になってき ている. 寸なわち，自動車は日本，米国，ヨーロッパ, あるいはアジア諸国で生産されており；各国の規制等 の事情に若干の相違はあるものの，世界基準に近い形 で標準的な製品基準が形成されている.これに対し， われわれの対象とする公共構造物（インフラストラク チャー) は基本的には単品・注文生産であるので, 自 動車のような形で世界に通用する基準が形成されるこ 
とは困難である. 公共構造物が基本的には, その場所, 土地に根ざし, 移動せず, しかも耐用年数が非常に長 く，その土地の文化・伝統に影響されることを考える と, 設計全体が統一的な一つの基準に統合されるとは 考えがたい.

とはいうものの, 設計の要因の中でも客観的な部分 に関しては，ある意味でのコンセンサスを得ることは できると思われるし，また必要なことであろう．たと えば，構造物の安全性については，その基本コンセプ ト，実現方法，評価法等について，一つの標準を示す ことができるのではないだろうか. 設計・施工基準の 国際標準化について真剣に取り組むことが痛感される ところである.

現在, 経済活動のグローバリゼーションは避けられ ないところである. 10 年前には国際競争は日米欧のみ で 10 億人しか関与していなかったが, 現在はアジア諸 国の参加もあり, 地球人口の 3 分の 2 である 40 億人が 関与している4).これらの経済活動のグローバリゼー ションの中にあって, 貿易の自由化と拡大の問題が米 国等を中心に議論され，わが国もWTO（世界貿易機 関）により問題の解決が迫られている.このような国 際化においてわれわれの分野でも, 欧米各国は軍事か ら経済に視点を移し, 技術規格, 技術者資格, 技術評 価の問題で先鞭を付けようとしている.ところが, 冷 戦構造の中で日本は一人繁栄を詔歌していたため, 世 界に目を向けず，対応が非常に遅れている. 特に, 土 木業界では, 海外進出は威信, ポーズあるいはやむに やまれず義理で行われた部分も否めず，利益を上げな くても大きな損失を被らなければよい, 利潤は国内の 仕事からで十分であるという風潮があったように思わ れる.

\section{(2) 国際設計標準}

国際標準が対象としている分野は,

1) 材料規格, 試験法, 検査法といった,「モノ」に 直接関係する分野

2) 品質管理の手順, 設計において確保すべき安全性 の水準やその確保法といった，「考え方」に関わ りが大きい分野

に分けて考えることができる．1）には，鋼材規格とか， 溶接の規格, 粒状体のふるい目の寸法, 地盤の支持力 試験法などが含まれる。こうした分野における国際標 準の策定には, 各国のデファクトスタンダードのせめ ぎ合いという側面がある. 日本も従来から一定の関心 を持って，しかるべき対応をしてきたといえる．ある 日突然公共工事の地盤調査に $N$ 值が使えなくなる, と いった状況を放置しておけば大変なことになるので,
積極的な対応が行われるのは当然のことであろう。こ れに対し 2)では，具体的にモノをどうするかというこ とではなく，多分に「手順」，「考え方」をどうするか という規格化の話であり，従前十分な対処がされてこ なかった分野である．設計した構造物を何年間使うつ もりか, 要求性能は何か, そのための条件は何か, と いうような具体的な設計条件に入る前の基礎となる条 件設定の方針の決め方に関するものである.

国際規格として, ISO (International Standard Organization : 国際標準化機構) 規格が有名である. ISO とは，物質およびサービスの国際交流を容易にし，知 的, 科学的, 技術的および経済的活動の分野の協力を 助長させるために, 世界的な標準化およびその関連活 動を発展，開発を図ることを目的に，1947 年 2 月 23 日に発足した非政府間国際機関である.

昨今, ISO 9000, ISO 14000 等の言葉をいたるところ で聞く．ところが，品質管理における国際規格は 1980 年頃から世界的関心を集めたが，当時わが国では TQC が花盛りで, ISOに対してあまり関心が持たれなかっ た. 土木学会においても，ISO に対する対応はあまり なされておらず, TC (Technical Committee) の審議団 体にもなっていなかった．それで，構造物関係の ISO 対応は, 日本建築学会, 日本コンクリート協会, 地盤 工学会, 日本鋼構造協会等に空口が設けられて対応し ていた.

こうした状況への危機感から，土木学会においても， 1996 年に長瀧重義新潟大学教授 (当時) を委員長とし て「ISO 調査検討委員会」が設置され，翌年「ISO 対 応特別委員会」が設けられ，各分野における対応状況 の情報収集と，対応策の協議が可能な態勢を整えるに 至った．特に「設計の基本」に関連する TC98につい ては，建築・住宅国際機構におかれた国内委員会（主 査 : 石山裕二北大教授）に土木関係の委員がほとんど 参画していない状況であったが，やはり 1997 年頃から 徐々に参加が増え, 現在では, 信頼性・耐震・風・波 浪など多岐にわたる専門家が活発に作業を行うに至っ ている5).

\section{a) ISO/TC98 の活動}

ISO 組織の中で，実際の規格を検討するのが，TMB （技術管理評議会）の下にある TC (専門委員会) であ る. ISO の専門業務は TCにより行われる. TC を設 置するための決定は TMB が行い，その活動範囲も承 認する．各 $\mathrm{TC}$ では，その中の種々の業務を扱う $\mathrm{SC}$ （分科会）および WG（作業部会）を設置できる.

$\mathrm{TC}$ のメンバー国は TC ごとに異なるが, 土木の重要 な分野の TC の多くは欧州諸国がメンバーの過半数を 占めている．欧州では統合に向けて CEN が Eurocodes 
の制定を進めており，CEN と ISO との重複を避ける ために CEN で規格案を作成しているものは ISO での 作業を行わないという協定を結んでいる.

その中で ISO/TC98 は, 材料に関係なく, 構造物の 設計の基本の規格化を目的としている. 用語と記号, 荷重, 力, 作用および変形の限界も含まれている. 全体 として構造に関わる基本的な信頼性要求の研究および 調整を行い, 関連した TC と連携して信頼性に対する 共通の取り組みの準備のために必要な材料 (鋼, 石, コ ンクリート，木など）を含む検討を行っている. TC98 の現状の組織は, SC1 (用語と記号 : 幹事国フランス), $\mathrm{SC} 2$ (構造物の信賴性の原則: 幹事国ポーランド), SC3 (荷重, 力, 作用: 幹事国イギリス) の 3 つに分かれて いる. なお，例外的に TC98 直轄として WG1，WG2 がある.これに対してわが国では, TC98 国内分科会, TC98/WG1 (構造物への地震作用), TC98/SC2/WG6 （既存構造物の評価）の国内検討委員会が建築・住宅国 際機構で開催されている.

\section{b) ISO 2394}

上記 ISO/TC98 を代表する国際標準が, 構造物の信頼 性に関する一般原則 (General Principles on Reliability for Structures) を記した ISO 2394 である.このまえが きに，その目的として「本国際基準は，あらゆる種類の 材料およびその組合せによるすべての建築物と土木構 造物の使用と建設に関する設計のルールを明らかにす るための共通の基礎を定めている」と嵒っている.も ちろん, 各国の事情を勘案し,「本国際基準は, 各国に おいて定まった使用条件下での耐用期間中の材料の特 性および構造物の性質とタイプを考慮した技術的およ び経済的条件に従って，国の基準，コードを作成する 責任を持つ委員会にとっての基礎として利用されるこ とを意図したものである」というように各国の事情も 考慮している.

本基準の構成は, 第 1 章範囲, 第 2 章定義, 第 3 章記 号, 第 4 章要求条件および概念, 第 5 章限界状態設計の 原則, 第 6 章基本変数, 第 7 章解析モデル, 第 8 章設計 の原則, 第 9 章部分係数による設計法, 第 10 章既存構 造物の評価, 付録からなっている. 内容は, Code for code writers であって, 前述したように概念の話が多 く, 実設計に直接関わるものではない. しかしながら, 共通の認識を持つために, 適用範囲, 用語の定義など が明確にされている. さらに, 構造物の安全性, 信頼 性の概念, そしてその確保に要求される条件が, 建設 中, 供用中すべてを網羅する形で言及されており, 信 頼性のレベルの明確化, 設計での対応策ならびにリス クの低減法等についても触れられている. 第 5 章以降 では, 限界状態設計に焦点を絞り, 限界状態の定義, 計
算に用いる基本変数, 解析モデルについて述べている. 確率に基づく設計法, 部分安全係数法について概略を 示し, さらに既存構造物の評価にも言及している. 本 文では，概念，考え方について述へ，もう少し具体的 な説明, 参考となるデータ，数値などは付録に示され ている，たとえば，破壊確率の計算法，荷重の組合せ， 部分係数決定のためのキャリブレーションの方法等が 具体的に記述されている.

当然のことながら，これらの内容に目新しいものは なく, ここ 20 年ぐらいの研究成果がまとめられてい る. しかし, 内容は多年の議論, 推敲を経たものであ るので, 記述されている内容にはかなりの統一性がみ られ, 個々の手法も現段階で最も妥当と思われるもの を採用している.

筆者のうち古田が委員長となり, 1998 年から 2000 年にかけて, 土木学会構造工学委員会の中に「構造設 計国際標準研究小委員会」を組織し，信頼性分野のみ ならず, 鋼・コンクリート・地盤・耐震等の各分野にお いて指導的立場にある専門家にも声をかけて，主とし てこの ISO 2394 の内容検討と, 設計法や安全性・信頼 性の問題についての, 今後の対応戦略について議論を 行う機会を得た.この小委員会活動の成果は,「例題を 含む ISO/TC98 および ISO 2394 の内容紹介」と「土 木構造物荷重指針作成に向けての枠組みとガイドライ

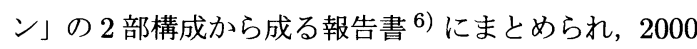
年夏に東京と大阪で報告会を実施した.また，この分 野についての関心が今後高まることを想定し, 報告書 は十分な部数を作成した（お問合せは筆者の佐藤まで お願い致します)，委員会のメンバー構成の守備範囲を 広げたのは，各分野の ISO 規定がこの ISO 2394 準拠 で書かれることになるため, 多くの方に内容を知って いただくことに意味があるという，ある意味では啓蒙 的な意味合いもあったのだが, 結果的には分野横断的 な作戦会議の機能ももつことができ, その後の ISO 対 応特別委員会をはじめとする各方面での議論に対して も，よいきっかけを作ることができたと考えている.

\section{c) Eurocodes}

ISO 2394 は概念, 精神規定で法律的な規制は持たな いが, Eurocodes は実際の設計に適用するために作成 されている.もちろん, 両者には密接な関係がある. Eurocodes は, 建築・土木構造物の構造物, 基礎の設 計標準を集めたものである，さらに，品質，施工性に 関わるものも含んでいる. Eurocodes 作成の目的は, 「Eurocodes は, 共通の建築物と土木構造物設計に関す る一連の規則を作成することにより，現在はメンバー 国間で異なっているこれらの規則を最終的に置き換え ることである」。 
表-1 Eurocodes

\begin{tabular}{l|l}
\hline Eurocode 1 & Basis of design and actions on structures \\
\hline Eurocode 2 & Design of concrete structures \\
\hline Eurocode 3 & Design of steel strucutures \\
\hline Eurocode 4 & $\begin{array}{l}\text { Design of composite steel and concrete struc- } \\
\text { tures }\end{array}$ \\
\hline Eurocode 5 & Design of timber structures \\
\hline Eurocode 6 & Design of masonry structures \\
\hline Eurocode 7 & Geotechnical design \\
\hline Eurocode 8 & Earthquake resistant design of structures \\
\hline Eurocode 9 & Design of aluminum alloy structures \\
\hline
\end{tabular}

Eurocodes は Eurocode 1 から Eurocode 9 までから なっており, Eurocode 2 から Eurocode 9 は構造物の 材料, 荷重のタイプ別の規定を決めようというもので ある. その詳細を表-1に示す。

これに対し, Eurocode 1 は各構造物共通の一般原則 に関する事項を扱っている.

Eurocode 1 は設計の基本 (Basis of Design) につい て記してあり, 安全性, 使用性, 耐久性に関する原理, 要求条件について述べている7). 読者として, 設計者, 施工者以外に，コード作成者，施主，規制・法律作成 者も視野に入れている. Eurocode 1 の内容は, 第 1 章 一般事項，第 2 章要求条件，第 3 章限界状態，第 4 章 外的作用，第 5 章材料特性，第 6 章幾何デー夕，第 7 章解析モデル，第 8 章実験に基づく設計, 第 9 章部分 安全係数による保証, それにA から D の 4 つの付録か らなっている. Eurocodes 作成は実に息長く進められ ており，その完成にはまだ 10 年ぐらいは必要であると 見込まれている.

\section{(3) 国際化における今後の課題}

現在, わが国は真の意味で国際化を必要としている. 国際化という言葉は過去何回もキーワードとして用い られ，現に大学にも「国際」という言葉をもつ学部が 多く新設されている，それ以前でも，歴史的に見て国 際化はわが国の常時取り組むべき課題であった．わが 国の歴史あるいは国民性を見てみると，日本人は国際 化といってはきているが，本当に国際化を望んでいた のかと考えてみると, どうもそうではないように思え る. 事実，そう分析している人もいる. 寸なわち，日 本の歴史を振り返ってみると, 日本国内で何か問題が 生じると, その打開策として目を海外に向ける，そし て国内の問題がある程度解決すると, 鎖国あるいはそ れに近い状態になってしまう。そして, 鎖国状態の方 がより好ましく, 独自の文化も発展するという具合で ある.このことは，江戸時代の鎖国，あるいは戦後の わが国の諸外国への対応および関係を見ると，ある程
度了解できるのではないだろうか.

構造設計の国際化あるいは国際標準という問題を考 えると，同様の状況が背景にあるように思える．国内 市場の逼塞感により，外圧を利用した市場経済システ ムの合理化，改変を目指し，新たな市場開拓としての 海外進出をせざるを得ない状況ではないだろうか.つ まり，国内では外国企業と価格，技術面でわたりあわ なくてはならず，海外で利益を上げることが必要とさ れているのである.ここで注意しなくてはならないの は，将来国内の景気が良くなれば，また鎖国状態に戻 れるのかといらことである. 現在の情報伝達のソフト， ハードの進歩を考えると，それは不可能であると思わ れる. そうであるならば, 今度こそ本腰を入れてこの 国際化の問題に取り組まなければならない.

そのためには，構造設計の本質にもどり，その基礎 を明確にし，概念・手法が国際的に通用する指針，基 準を持つことが必要不可欠である，土木業界を見ると， この認識がまだ希薄であると言わざるをえない，今ま で述べてきた ISOへの対応もしかりである.

まず，国際設計標準ということからは，ISOへの対 応を十分に行い，国際規格にわが国の意見が十分取り 入れられ，わが国の技術体系が国際的に認知され，存 続できるようにすることが重要である.そのためには, ISO の TC 委員会等に積極的に参加, 貢献することが必 要である.また，そのためのわが国の対応組織の整備 も必要である. わが国の風潮として，外国の基準を取 り入れてそれに適応していけばよいという考えがある が, この考え方では現在われわれが直面している問題 を解決することは不可能である．ISO 9000, ISO 14000 等への各企業の取り組み方から，もう二度と ISO とい う言葉は聞きたくないということも理解できるが，い まわが国が置かれている立場をよく認識し，真の国際 化への取り組みを行わなければならない.

\section{5. おわりに}

現在のわが国を取り巻く社会, 経済, 自然環境を考 えると，構造物の安全性向上・長寿命化を実現させる ことが肝要である．そのためには，信頼性理論に基づ く性能照查型設計が有力な手段と考えられる. 長寿命 化という観点からは, 初期の設計に維持管理の効果, 役 割を積極的に考慮することが必要不可欠である．すな わち，合理的な維持管理を達成するには，性能照査型 設計が有効である．つまり，維持管理においては，同 じ状況，状態が全く存在せず，また実物があるだけに 合理性, 経済性に裏づけられた説明能力が必要となる. 
以上のことから，性能照査型設計が今後の設計基淮 として一つの有力な手段を提供することは疑うべきも ないが，実際の設計基準制定には，誰がどのような形 で性能を規定するのか, 誰がどのような方法で照査す るのか等の課題がある. しかも, 契約, 発注体系とと もに保険との関わりも考慮しなくてはならない, さら に，新たな設計基準は国際的に通用する考え方に基づ いた設計基準でなければならない。このようにグロー バルな視点が必要ではあるが同時に日本の示方書とし て日本固有の文化，風土，環境条件を十分に反映させ ていることが望まれる.

構造技術者の目的は，「良い構造物」を作ることであ る. それには，その「基本概念」を明確にし，誰にでも きちんとした形で説明できなければならない.そうし てこそ国際的に認知されることになる．もちろん，わ が国独自の設計基準が確立でき，それが国際的に認め られればそれに越したことはない。しかしながら，現 在のヨーロッパ諸国つまり EU の動きを見れば，時期 を逸していると言わざるを得ない，現実的な対応とし ては, 何回も言ってきたように, ISO の TCに意見を反 映させることが急務であり，それと同時に APEC 諸国 における地域規格，すなわち CEN (Comite Europeen de Normalization) 並のものの確立を目指すことも考え られる. 事実, APEC 諸国での鋼構造協会が後援する 組織の設立も試みられている.もちろん，米国の動向 にも注意を払うべきことはいうまでもない.

公共構造物の安全性の基本理念, 概念を明確にする ことは重要であるが，このためには，技術的な観点か らだけではなく, 経済性, 社会性を考慮した総合的な 観点からの議論が必要である。経済性, 社会性（その 国の文化, 歴史) を考えると, 構造物の安全性もその 国の独自性が反映される必要があろう.

本文は, もともと 4.(2) で紹介した, 構造工学委員会 構造設計国際標準研究小委員会の活動報告として企画 されたものであったが, 著者らの身近なところで状況 が刻々変化していることに比して，存外にその重要性 が十分認知されていないのではないかという意識もあ り,このようなまとめ方をした. 最後に, この小委員会 で今後検討すべきと考えている課題を紹介して，ここ でのまとめとする. 本小委員会の目的は, 国際設計標 準の重要性の宣伝普及と新しい設計基準の模索であっ たが, このためのテーマとして, 安全性の哲学, 限界 状態, 要求性能, ISO 2394 の理解, 教宣, ISO に基づ く設計手順の例示集の作成, 土木建築統一基準の可能 性, 荷重指針（地震荷重, 荷重の組合せ), 地震と劣化, 耐久性, 各種データベースの整備などが挙げられてい る.また, これに関連した活動として, 地震工学委員
会の国際委員会の動きや, ISO 特別委員会を軸とした 耐震設計法の国際標準化の動き，また，地盤関係を中 心に提案されてきた包括設計コード（日下部治東工大 教授・本城勇介岐阜大教授を中心としたメンバー）の 概念を，各分野に対しても適用性をさぐる動きなどが 注目される．さらに，国土交通省では，建設省時代の 3 年ほど前から, ISO $2394 \cdot$ Eurocode 0 対応と, 分野 間の整合化を意図して「土木・建築にかかる設計の基 本」が検討されてきたが， 2002 年 3 月に最終報告がま とまっている.この草案をまとめる幹事会には, 上記 国際標準委員会との重複も多く, 問題意識は同一線上 にあるといってよいであろう。

なお，本報告では，構造関係のみに焦点を当ててい るが, 地盤工学関係, コンクリート工学関係について は参考文献の 8) から 11) 等を参照されたい.

謝辞 : 本文は, 土木学会構造工学委員会構造設計国際 標準研究小委員会での活動成果を基に著者の意見を述 べたものである.ここに同小委員会各委員に対して深 甚なる謝意を表する.

\section{参考文献}

1) 土木学会関西支部：限界状態設計法, 昭和 62 年度講 習会テキスト, 1987 .

2) 家村浩和 : 極限地震動に対する要求性能と設計法のあ り方一耐震設計から先端技術を応用した免振・制振設 計一一, 土木学会論文報告集, No.623/VI-43, pp.1-8, 1999.6 .

3) 大塚久哲 : 耐震基準の性能設計化の現状と今後の課題, 橋梁と基礎, Vol.33, No.6, pp.39-43, 1999.6.

4) 池田駿介 : 土木学会が危ない, 土木学会誌, Vol.83, pp.17-20, 1998.

5) 佐藤尚次 : 特集・橋梁技術の国際展開; 設計法の国際 標準に向けてどう対応していくべきか，橋梁と基礎， Vol.34, No.8, pp.71-74，2000.8.（なお，この特集全 体も本文の参考文献として推奨するにふさわしい)

6) 活動成果報告書 : 国際標準に基づく構造物の設計法, 土木学会構造工学委員会構造設計国際標準研究小委員 会, 2000.8 .

7) Gulvanessian, H. and Holicky, M. : Designers' Handbook to Eurocode 1, Thomas Telford, 1997.

(注 : Eurocode 1 は, 同書出版後,「設計の基本」の 0 と「構造物への作用」の 1 に分割された）

8) 活動成果報告書 : In Search of Excellence for World Compatible Consulting, 土木学会建設コンサルタン ツ委員会構造設計の国際化対応に関する研究小委員会, 2000.7.

9）本城勇介：限界状態設計法による基礎構造物モデル設 計コードの提案, 平成 11 年度科学研究費補助金最終 報告書, 2000.3 .

10）本城勇介 : 欧州における基礎構造物・地盤構造物設計 コードに関する調查, 2001.10.

11）田辺忠顕, 六郷恵哲: 国際標準化機構第 71 専門委員会 第 7 回総会報告, コンクリート工学, Vol.36, No.12, pp.42-46, 1998.12 .

(2002.5.23 受付) 